\title{
Postbiotics, Metabolic Signaling, and Cancer
}

\author{
Nikola Vrzáčková, Tomáš Ruml (D) and Jaroslav Zelenka *(D) \\ Department of Biochemistry and Microbiology, University of Chemistry and Technology Prague, \\ 16628 Prague, Czech Republic; Nikola.Vrzackova@vscht.cz (N.V.); Tomas.Ruml@vscht.cz (T.R.) \\ * Correspondence: Jaroslav.Zelenka@vscht.cz; Tel.: +420-22044-5207
}

Citation: Vrzáčková, N.; Ruml, T.; Zelenka, J. Postbiotics, Metabolic Signaling, and Cancer. Molecules 2021, 26, 1528. https://doi.org/10.3390/ molecules 26061528

Academic Editors: Silvie Rimpelová and Farid Chemat

Received: 9 February 2021

Accepted: 9 March 2021

Published: 11 March 2021

Publisher's Note: MDPI stays neutral with regard to jurisdictional claims in published maps and institutional affiliations.

Copyright: (c) 2021 by the authors. Licensee MDPI, Basel, Switzerland. This article is an open access article distributed under the terms and conditions of the Creative Commons Attribution (CC BY) license (https:/ / creativecommons.org/licenses/by/ $4.0 /)$.

\begin{abstract}
Postbiotics are health-promoting microbial metabolites delivered as a functional food or a food supplement. They either directly influence signaling pathways of the body or indirectly manipulate metabolism and the composition of intestinal microflora. Cancer is the second leading cause of death worldwide and even though the prognosis of patients is improving, it is still poor in the substantial part of the cases. The preventable nature of cancer and the importance of a complex multi-level approach in anticancer therapy motivate the search for novel avenues of establishing the anticancer environment in the human body. This review summarizes the principal findings demonstrating the usefulness of both natural and synthetic sources of postbotics in the prevention and therapy of cancer. Specifically, the effects of crude cell-free supernatants, the short-chain fatty acid butyrate, lactic acid, hydrogen sulfide, and $\beta$-glucans are described. Contradictory roles of postbiotics in healthy and tumor tissues are highlighted. In conclusion, the application of postbiotics is an efficient complementary strategy to combat cancer.
\end{abstract}

Keywords: microbiome; colorectal cancer; intestinal metabolome; GPR81; SCFA; functional food

\section{Introduction}

The gastrointestinal tract is colonized by a variety of different microorganisms, the so-called intestinal microbiome. This dynamic ecosystem is formed by a pool of 400-1000 adherent and non-adherent bacteria species [1], with approximately 1011 bacteria per gram of intestinal content [2]. Despite significant differences between the compositions of gut microbiomes in humans, their functions are very similar. They are responsible for the fermentation of indigestible food components into absorbable metabolites [3], detoxification of pollutants [4], and synthesis of a number of vitamins, mostly vitamin $\mathrm{K}$ and some water-soluble vitamins B [5], and they minimize contact with ingested bacteria, reduce the growth of pathogenic flora, and regulate the immune system [6]. The absorption of microbial metabolites into the circulation is responsible for the projection of its effects beyond the gut called the gut-body-brain axis due to the influence on the whole body signaling including the brain $[7,8]$.

Any imbalance of gut microbiota, so-called dysbiosis, therefore, negatively influences the overall health of the host. While acute dysbiosis caused by food poisoning or antibiotic treatment is associated with temporary symptoms and does not necessarily need treatment with high-risk drugs [9], chronic dysbiosis has been linked to serious chronic diseases headed with autoimmune diseases, allergies, psychiatric disorders, obesity, and even cancer [10]. Therefore, the manipulation of the composition and the overall metabolism of intestinal microflora has been suggested as an effective preventive and therapeutic strategy to combat cancer and other diseases. Currently, there are four major types of such intervention: prebiotics, probiotics, synbiotics, and postbiotics. The definitions are as follows:

- Prebiotics are non-digestible food ingredients that beneficially affect the host by selectively stimulating the growth and/or activity of a limited number of bacteria in the colon, thus improving the host's health. 
- Probiotics are living microorganisms that, when administered in adequate amounts, confer a health benefit on the host.

- Synbiotics are combinations of prebiotics and probiotics that have beneficial effects on the gut microbiome.

- Postbiotics are substances released by or produced through the metabolic activity of the microorganisms which directly exert beneficial effects on the host [7].

While the research on probiotics has begun more than 100 years ago, postbiotics are a newcomer in the field of science, even though the beneficial effects of fermented food have been known for millennia [11]. Until recently, the studies have been focused on the effects of probiotics, mainly lactic acid-producing bacteria such as Lactobacillus or Bifidobacterium, and on prebiotics such as dietary fiber, human milk oligosaccharides, lactulose, and inulin derivatives. However, the increasing body of evidence suggests that the overall metabolism of the intestinal microflora is more important than the presence or absence of any particular microbial species. The postbiotics research was initiated by studies employing the cell-free supernatants (CFSs) from bacterial fermentation followed by primary microbial metabolites such as lactic acid and short-chain fatty acids (SCFA) [12-16]. However, there are numerous other interesting molecules including the odorous gas hydrogen sulfide $\left(\mathrm{H}_{2} \mathrm{~S}\right)$ and a group of polysaccharides with mixed prebiotic/postbiotic properties called $\beta$-glucans. While several recent high-quality reviews covered the relationship between the intestinal microbiome and cancer [17-22], we focused on the available data on postbiotics and cancer with a special emphasis on metabolic signaling.

\section{Metabolic Signaling in Cancer}

Here, we hypothesize that an important component of the anti-cancer effects of postbiotics is the induction of cell response to metabolic and oxidative stress. As microbial metabolic waste products, postbiotics disturb the metabolic homeostasis of host cells, causing metabolic and oxidative stress. Lactate has been shown to stimulate mitochondrial production of reactive oxygen species (ROS) by increasing the NADH/NAD ${ }^{+}$ratio and serving as a substrate of lactate oxidase [23]. Butyrate has also been shown to stimulate ROS levels, although the exact mechanism is unknown [24]. $\mathrm{H}_{2} \mathrm{~S}$ covalently modifies sulfhydryl moieties of proteins and inhibits mitochondrial cytochrome c oxidase enhancing the ROS release [25]. Even $\beta$-glucans have been demonstrated to cause oxidative stress in cancer cells [26].

The adaptive response of the cells is driven by increased activity of stress signaling pathways, including, but not limited to, the energy sensor AMP-activated protein kinase (AMPK), the family of sirtuin deacetylases (SIRT1-7), the metabolic transcription coactivator PGC1 $\alpha$, the antioxidant transcription factor NFE2L2 (Nrf2), and the stimulation of specific survival processes including mitochondrial biogenesis and autophagy [23]. The enhanced stress signaling protects normal tissues against carcinogenesis by suppressing cell proliferation, mutagenesis, and tissue inflammation. Specifically, AMPK activity mimics the cancer-preventing effects of caloric restriction by enhancing autophagy and suppressing mTOR signaling [26]. It is also an activator of sirtuins and PGC1 $\alpha$ that inhibit the cell cycle and nuclear factor kappa B (NFkB) signaling [27]. In addition, Nrf2-driven transcription stimulates the antioxidant, detoxification, and DNA repair capacity of the cells [23]. It is important to note that butyrate induces Nrf2 directly through its effect on histone acetylation [28,29].

On the other hand, the increased production of mitochondrial ROS accompanied by the enhanced stress signaling frequently occurs in cancer cells as a byproduct of metabolic transformation. Moreover, it is indispensable for the progression of the established malignant tumors due to its pro-survival effect $[23,26]$. However, such deregulated signaling may be overwhelmed by external metabolic stress, including postbiotics. Therefore, postbiotics also suppress the progression of established tumors by exaggerating the metabolic and oxidative stress, causing programmed cell death [23-27] (Figure 1). The suggested roles of postbiotics in stress response will be documented throughout the present review. 


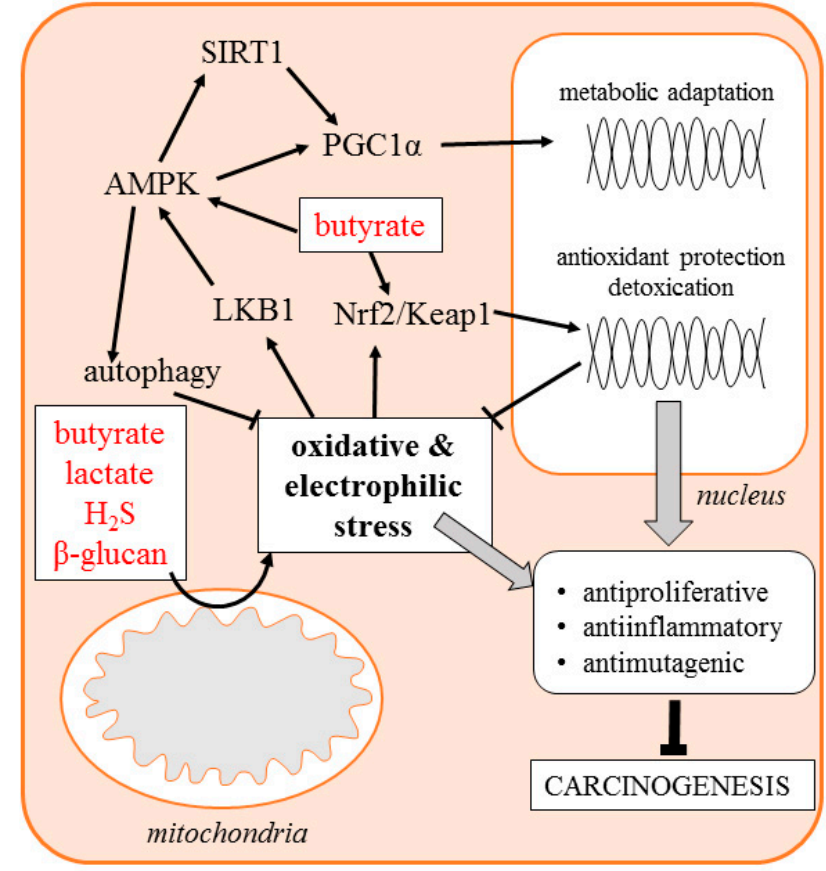

NON-CANCER CELL

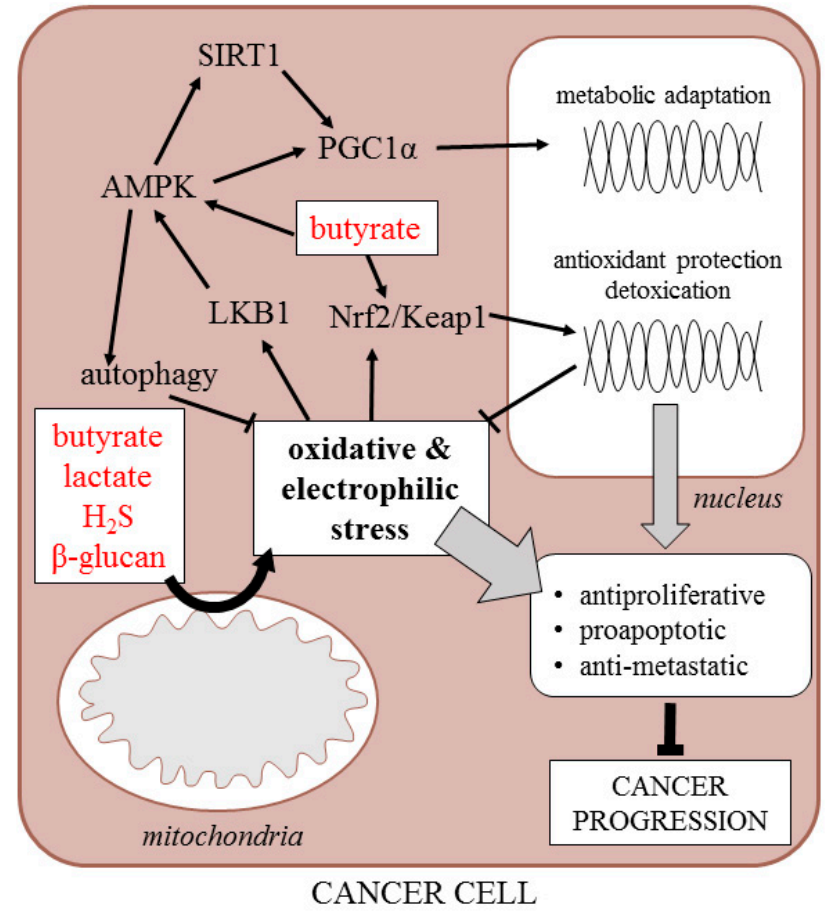

(b)

Figure 1. Signaling response of non-cancer (a) and cancer cell (b) to postbiotics (AMPK-5' AMP-activated protein kinase, $\mathrm{H}_{2} \mathrm{~S}$-hydrogen sulfide, Keap1-Kelch Like ECH Associated Protein 1, LBK1-liver kinase B1, Nrf-2-Nuclear factor erythroid 2-related factor 2, PGC1 $\alpha$-Peroxisome proliferator-activated receptor gamma coactivator 1-alpha, SIRT1Sirtuin 1).

\section{Cell-Free Supernatants}

CFSs are typically prepared by centrifugation of microbial cultures followed by filtration. It was shown that these solutions have anti-inflammatory, antioxidant, antibacterial, antiinfectious, and anticancer effects [7]. The protective effects of CFSs were described for all the stages of tumorigenesis, including the initiation, growth, and metastatic dissemination.

In 2019, Bahmani et al. reported the suppressive effects of Bifidobacterium bifidum on the proliferation of human colon cancer cell line SW742 in vitro. It was demonstrated that even the CFSs from these bacteria can reduce the growth of tested cancer cell line [30]. In addition, Kim et al. showed the inhibition of cancer cells growth by CFS from Bifidobacterium adolescentis SPM0212 using the three colon cancer cell lines Caco-2, HT-29, and SW-480 [31].

In 2012, Escamilla et al. published a study connecting CFS with cancer cell invasion. They used CFSs from two species: Lactobacillus casei and Lactobacillus rhamnosus GC, which were tested in vitro on human colorectal cancer cell line HCT-116. The main focus of this study was the effect of CFS on the ability of cancer cells to form metastases [12]. During the process of metastasis, there are two main steps: the induction of matrix metalloproteinases that degrade the components of extracellular matrix, such as collagen, fibronectin, and gelatin [32], and the loss of tight junction proteins, such as occludin, claudin, or zona occludens 1, 2, or 3, that exist between enterocytes [33]. It was shown that both CFSs reduced invasion of HCT-116 in vitro by decreasing the activity of metalloproteinases and increasing the level of zona occludens protein [12].

In 2020, a study was published linking the initiation of carcinogenesis with CFS application. CFS from Lactobacillus plantarum prevented tumor development in high-fat dietfed C57BL/6-APC ${ }^{\mathrm{Min} /+}$ mice. This effect was achieved by enhancing the immune system, downregulating the inflammatory NF- $\mathrm{KB}$ and Wnt signaling pathways, and balancing the gut microbiota composition towards healthy control [34]. 
Finally, a supernatant from Lactobacillus plantarum could also reverse the resistance of colorectal cancer cells HT-29 and HCT-116 to 5-fluorouracil therapy by inactivating the Wnt/ $\beta$-catenin signaling pathway [35].

\section{Short-Chain Fatty Acids}

The most studied postbiotics are SCFA, namely acetate, propionate, and butyrate. These molecules are products of dietary fiber fermentation by gut microorganisms, mainly Faecalibacterium prausnitzii and Eubacterium rectale [31]. SCFA contribute to $5-15 \%$ of the total caloric requirements of humans and the molar ratio of acetate:propionate:butyrate is approximately 60:20:20 [36,37].

The total production of intestinal SCFA is difficult to determine because $95 \%$ is taken up by colonocytes and metabolized [36]. Acetate and propionate are primarily transported to muscles and the liver, where they serve as substrates for mitochondrial oxidation. In contrast, butyrate is metabolized in situ by colonocytes [38], where it makes up to $70 \%$ of the energy demand [39]. Lower levels of intestinal SCFA were associated with the occurrence of advanced colorectal adenoma [40]. Since butyrate is the most-studied postbiotic, the next chapters will discuss in detail its role in cancer prevention and therapy.

\subsection{Import to the Cells}

As a small hydrophobic molecule, butyrate is able to diffuse through the membrane on the apical side of colonocytes [41]. In addition, two types of transporters also selectively import it: Monocarboxylate Transporter 1 (MCT1) and Sodium-coupled Monocarboxylate transporter 1 (SMCT1), both expressed on the apical side of the intestinal epithelium [42,43].

MCT1 employs a symport with $\mathrm{H}^{+}$ions driven by a transmembrane gradient affecting the intracellular $\mathrm{pH}$ [44]. The presence of inflammation including inflammatory bowel disease or early stages of colorectal carcinogenesis is connected to the downregulation of MCT1 expression [45,46]. On the other hand, advanced stages of colorectal carcinoma (CRC) are associated with an upregulation of MCT1 expression [47] due to the intratumoral production and metabolism of lactate, another MCT1 substrate. Interestingly, physical activity, which is known to reduce the risk of CRC, increases MCT1 protein and its activity in muscle [48].

Butyrate transport through the SMCT1 is connected with a symport of one $\mathrm{Na}+$ ion [49]. Similar to MCT1, factors that are responsible for the development of early colon tumorigenesis, for example, inflammation or obesity, downregulate the expression of SMCT1 [50-52]. SMCT1 is also silenced in thyroid, head and neck, breast, stomach, prostate, pancreas, and blood cancer [51,53]. A much less-described way how to transfer SCFA to the cell is by using the SCFA/ $\mathrm{HCO}_{3}{ }^{-}$exchange [54].

One of the transporters located on the apical side of the cell is the Breast Cancer Resistance Protein (BCRP). Butyrate is transported through BCRP coupled with ATP hydrolysis [55]. Interestingly, a malignant transformation of the colon epithelium is accompanied by a significant downregulation of BCRP and accumulation of butyrate in the cell [56]; however, in colorectal invasive cancer, this protein is upregulated and its level can be correlated with the ability to create metastases $[57,58]$.

Considering the import of butyrate to the cell, it is also very important to mention the export [55]. A transporter located on the basolateral side that is responsible for the efflux of butyrate, Monocarboxylate transporter 4 (MCT4), is also connected with a symport of proton [59].

\subsection{Mechanism of Action}

\subsubsection{Metabolism}

When transported to the cell, butyrate is quickly metabolized. In colonocytes, the roles of butyrate are very broad, including being the main source of energy, supporting growth and proliferation, protecting from apoptosis, inhibiting colorectal carcinogenesis, inflammation, and oxidative stress, and promoting angiogenesis [60]. In contrast, the role of 
butyrate in colon cancer cells is very different. Here, the butyrate supports differentiation, suppresses the proliferation, and evokes oxidative stress, leading to cell cycle arrest and apoptosis. Opposite roles of the butyrate in normal and cancer cells contribute to the phenomenon called "butyrate paradox" [60], which has not been explained until recently (Figure 2).

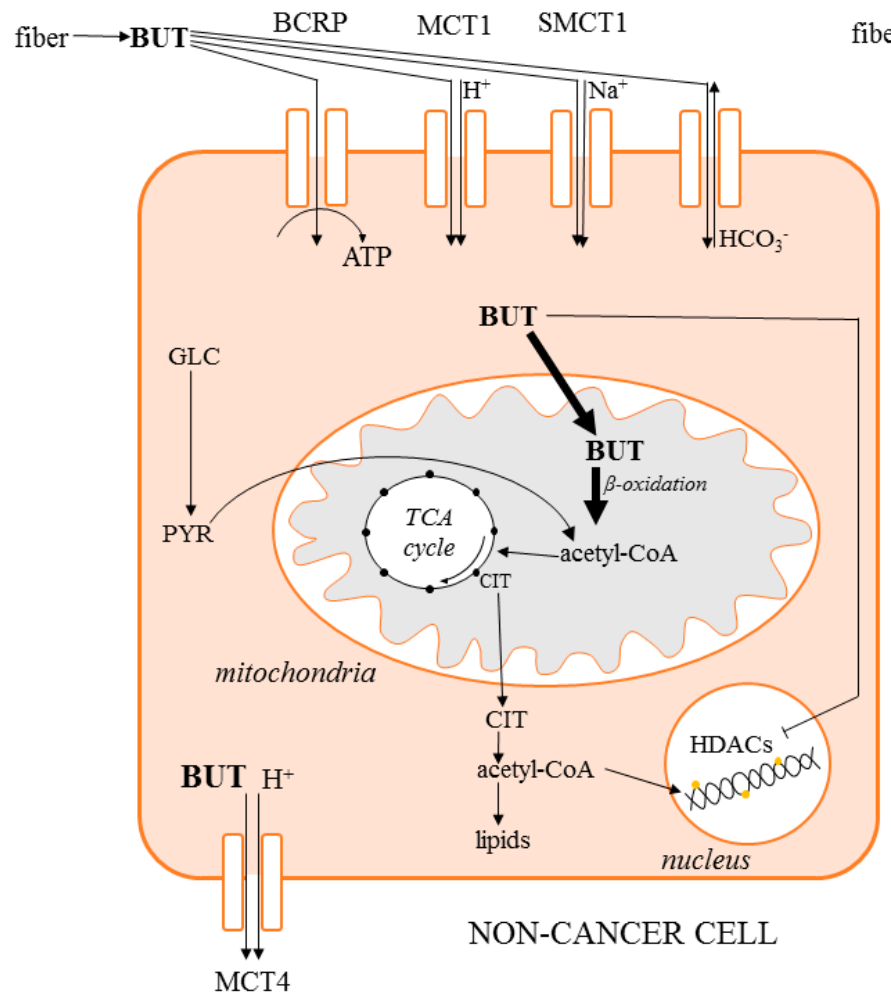

(a)

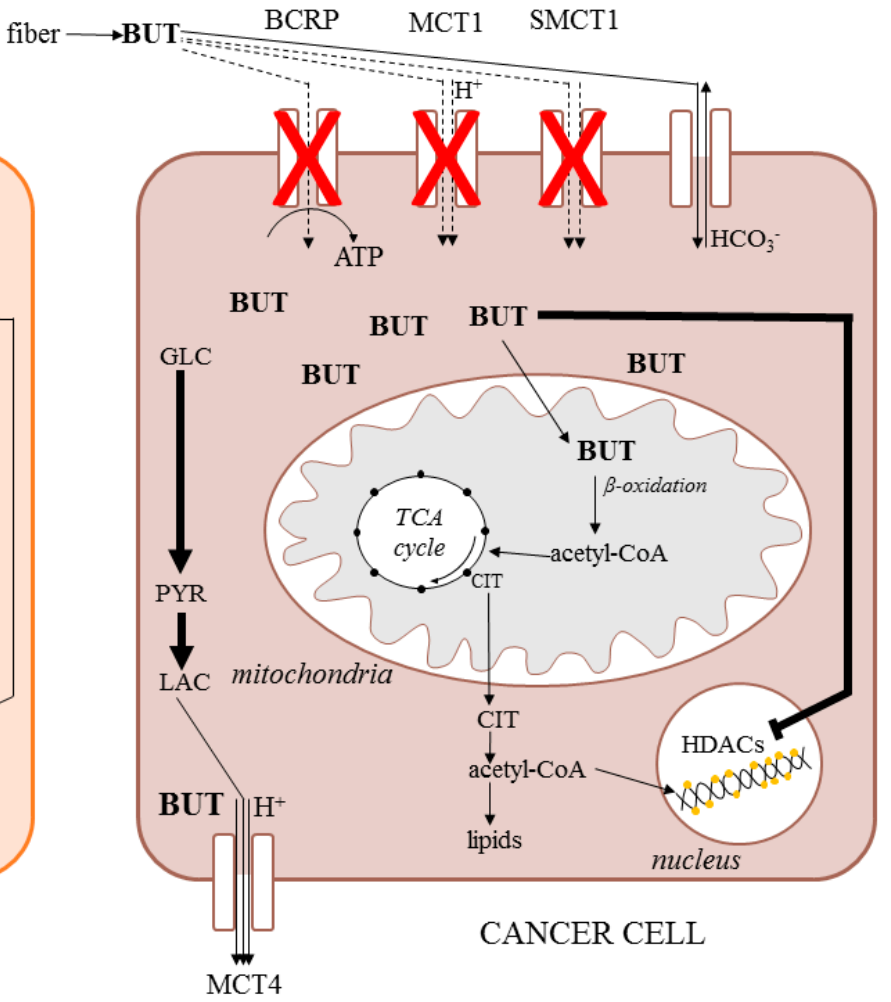

(b)

Figure 2. Import and metabolism of butyrate in non-cancer (a) and cancer cell (b) (BCRP—breast cancer resistance protein, BUT—butyrate, CIT—citrate, HDACs—histone deacetylases, MCT—monocarboxylate transporter, GLC—glucose, LAC—lactate, PYR—pyruvate, TCA—tricarboxylic acid cycle).

In a non-cancer cell, butyrate is metabolized by $\beta$-oxidation, accompanied by the utilization of acetyl-CoA in the Krebs cycle [61]. In cancer cells, the main source of energy is glucose, which is metabolized via glycolysis to lactate, a phenomenon called the Warburg effect, which is associated with the suppression of $\beta$-oxidation. Thus, molecules of butyrate accumulate in the cancer cell cytoplasm, migrating to the nucleus, where they act as inhibitors of histone deacetylases (HDACs). Under these conditions, the histones are acetylated and the solid structure of DNA becomes loose and accessible to the transcription factors, leading to the expression of different proteins, triggering oxidative stress and eventually apoptosis [62-64].

\subsubsection{Oxidative Stress}

Oxidative stress is a result of the imbalance between the levels of prooxidative reactive oxygen and nitrogen species and the levels of antioxidant enzymes and scavengers that protect the cell against the oxidation of macromolecules [65].

A study by Abrahamse et al. showed that pretreatment of isolated distal colon cells with butyrate or acetate decreased the oxidative damage caused by hydrogen peroxide and stimulated the DNA repair and the antioxidant defense system. On the other hand, an increase of intracellular calcium induced by hydrogen peroxide was not changed by the presence of butyrate [14]. Therefore, butyrate may serve as a chemopreventive agent [66]. 
Similar results were obtained in the study of Rosignoli et al. dealing with freshly isolated human colonocytes and colon cancer cells. The $\mathrm{H}_{2} \mathrm{O}_{2}$-induced DNA damage was counteracted by butyrate and a mixture of SCFA, where butyrate was the most active component [67].

Other studies focused on the connection between antioxidant enzymes and SCFA. A study by Sauer et al. pointed to the ability of primary colon cells treated with butyrate to increase the expression of catalase and metallothionein while reducing the levels of cyclooxygenase-2, suggesting an antioxidant and anti-inflammatory effect. However, the levels of superoxide dismutase and glutathione-S-transferase were reduced [13]. In contrast, evidence of a butyrate-induced increase in glutathione-S-transferase levels in primary colonocytes and colorectal adenocarcinoma cells, but also premalignant adenoma, was reported [68-70].

\subsubsection{Autophagy}

Autophagy (self-eating) is a complex pro-survival pathway triggered by nutrient depletion, starvation, or hypoxia. Proficient autophagy is indispensable for tumor progression. However, deregulated and excessive autophagy may cause autophagic cell death [71].

Butyrate was shown to be the inducer of autophagy in colorectal carcinoma cell lines through the aggravation of endoplasmic reticulum stress. Mechanistically, butyrate stimulated the liver kinase B1/AMP-activated protein kinase (LKB1/AMPK) signaling pathway $[72,73]$.

\subsubsection{Invasion}

The metastatic dissemination of tumors to distant sites is a multifactorial process estimated to be responsible for $90 \%$ of cancer deaths. An indispensable facilitator of metastasis is the ability of cancer cells to cleave the components of the extracellular matrix, which is provided by the matrix metalloproteinases (MMPs), a group of zinc-dependent endopeptidases upregulated in invasive tumors [32]. Another factor is the number of tight junctions between the cells in the primary tumor [74] and the levels of adhesion molecules such as CD44, which is capable of the cell-cell and cell-matrix interactions responsible for the colonization of distant sites [75,76].

In the study of Zeng and Briske-Anderson, the prolonged treatment of fibrosarcoma cells HT1080 with butyrate have shown the increased levels of MMP-2 and MMP-9 proteins but also increased the levels of tissue inhibitors of metalloproteinase-1 (TIMP), which altogether resulted in the decreased ability of these cells to create metastases [77].

Barshishat et al. focused on the levels of adhesion protein CD44 in the highly metastatic human colon cancer cell line HM7. They showed a significant decrease of CD44 after treatment with butyrate and a complete loss of HM7 ability to form metastases in the liver of nude mice [78]. Taken together, butyrate is capable of affecting the potential of cancer cells to metastasize even under in vivo conditions.

\subsubsection{Apoptosis}

The main features of apoptosis are the condensation of chromatin, the fragmentation of nuclei followed by the appearance of the apoptotic bodies, the loss of inner mitochondrial membrane potential, the release of cytochrome $\mathrm{c}$ to the cytoplasm, and the activation of specific proteases—caspases [79].

Already in 1993, Hague et al. showed that physiological concentrations of sodium butyrate induce apoptosis, which was accompanied by a detachment of cultured cells from the surface to the medium. In some of the tested colonic cell lines, over $80 \%$ of the cells were apoptotic with internucleosomal DNA fragmentation. The percentage of apoptotic cells was more significant for carcinoma cells compared to the adenoma cell lines $[16,80]$.

The study of Chirakkal et al. investigated the mechanism of cell death after the treatment with butyrate in three colorectal cell lines. BAK pro-apoptotic protein levels were shown to be significantly increased, while Bcl-like anti-apoptotic protein levels were 
decreased. The study indicated that BAK is upregulated at the transcriptional level through increased binding of transcriptional factors to the promoter due to the typical inhibition of HDACs, leading to a loose DNA structure [81].

\subsection{Tributyrin}

Tributyrin, a triacylglycerol containing three molecules of butyrate, was tested as a postbiotic agent to avoid the disgusting odor and short half-life of free butyrate. Several in vitro studies on different cancer cell lines showed that tributyrin induces apoptosis at millimolar levels [82-88]. More importantly, the treatment with tributyrin also induced apoptosis in some in vivo studies. Giermasz et al. showed that the systematic administration of tributyrin significantly retarded the growth of B16F10 melanoma in mice [85]. This effect was also observed in another in vivo study on mice with transplanted prostate cancer cell lines [86]. These results motivated phase I clinical trials for tributyrin tolerability in cancer patients, which proved good tolerance and promising effects on the disease progression [87]. In addition, the preventive effects of tributyrin also deserve attention. The treatment with tributyrin reduced the frequency of preneoplastic lesions in a rat model of chemical hepatocarcinogenesis [88]. Tributyrin feeding also protected against intestinal injury and inflammation in various animal models, both phenomena being well-known contributors to intestinal carcinogenesis $[89,90]$.

Taken together, tributyrin is a candidate chemopreventive drug triggering the cancer cell apoptosis, modulating the histone acetylation, and having a longer half-life compared with the butyrate.

\section{Lactic Acid}

\subsection{Import to the Cell}

Lactate, the anion of lactic acid, is accumulated in the cells by two main classes of transporters: a group of monocarboxylate transporters (MCTs) and a group of lowaffinity sodium-coupled monocarboxylate transporters (SMCT2). The MCT family has 14 members with MCT1-4 being specific for the lactate, pyruvate, and ketone bodies in a proton-dependent manner [91,92].

MCTs are highly expressed especially in muscles, liver, kidney, intestine, and brain, but also in tumor tissue. MCT1 is a high-affinity, low-capacity preferential importer of lactate, while MCT4 is a low-affinity, high-capacity preferential exporter of lactate. Both MCT1 and MCT4 are dominant forms of MCTs, and are highly expressed in tumors [93].

The SMCT2 class contains only two members abbreviated SLC5A8 and SLC5A12. SLC5A8 is selective not only for lactate but also for SCFA and nicotinate [94]. SMCT2 is localized in only three tissues: kidney, small intestine, and skeletal muscles. The available data suggest that the main role of SMCT2 is the uptake of lactate from dietary sources [95].

\subsection{Lactate Signaling}

Lactate is a natural, high-affinity substrate, for the $G$ protein-coupled surface receptor called GPR81. GPR81 is highly expressed in the adipose tissue and its pleiotropic signaling roles were also demonstrated in skeletal muscle, immune cells, and the central nervous system [96]. GPR81 is also upregulated in tumor tissue, and its crucial role in disease progression, metabolic flexibility, and immune evasion was demonstrated [97-101].

Another mediator of lactate signaling is the elevation of ROS production in mitochondria upon lactate exposure [102,103]. Lactate-derived ROS alone and in combination with GPR81 signaling is responsible for the stimulation of the stress response signaling including the AMPK, PGC1 $\alpha$, and mitochondrial biogenesis. The elevated stress response signaling is associated with a cytoprotective phenotype called mitohormesis $[103,104]$.

\subsection{Dual Role of Lactate in Cancer}

The role of lactate, MCTs, and GPR81 in the tumor microenvironment is predominantly driven by the Warburg effect, i.e., enhanced glycolysis and lactate secretion of cancer cells 
even at normoxia, resulting in the tumor lactate levels reaching $10-20 \mathrm{mmol} \cdot \mathrm{L}^{-1}$, while the normal concentration is around $1-2 \mathrm{mmol} \cdot \mathrm{L}^{-1}$ [105].

The endogenously produced lactate in the established tumors has been identified as a driver of angiogenesis, immune evasion, metastasis, and resistance to therapy [106]. On the other hand, lactate delivered by postbiotic supplementation may serve as an inhibitor of carcinogenesis through the maintenance of the epithelial integrity and downregulation of the tissue inflammation [11,107-111].

\subsection{Cancer Prevention with Fermented Dairy Products}

Even though there is significant evidence regarding the chemopreventive properties of fermented food, especially dairy products, these studies are rather phenomenological without identification of the active compound(s) responsible for the effect. On the other hand, the main microbial components of fermented dairy products are lactic acid-producing bacteria (LAB). It is well known that LAB convert lactose in dairy products to lactic acid. There is about $0.9 \%$ of lactic acid in yogurts and $2 \%$ in kefirs. Food with such healthpromoting properties is termed "functional food." Based on the available data, it is likely that lactic acid is involved in the beneficial effects of fermented food.

In 2008, a large prospective study of the effect of fermented milk on 82,002 Swedish women and men was published. This study was focused on bladder cancer because most metabolites are excreted through the urinary bladder, providing a visible effect of orally administered dairy products. The results suggest that a high intake of cultured milk may reduce the risk of developing bladder cancer [112]. The results were later confirmed in a meta-analysis of available studies [113]. Other studies have shown that regular consumption of yogurt but not milk decreases the incidence of colorectal cancer in Europe and the US [114-116]. A higher adolescent dairy intake was associated with lower rectal and advanced adenoma risk later in life in a large cohort of nurses [117]. A regular yogurt intake versus a rare intake was associated with decreased odds of hyperplastic polyps and adenomatous polyps in the colon [118]. Taken together, postbiotic lactic acid may serve as a prevention of cancer, but further studies are needed to distinguish its effects from the other components of dairy products.

\section{Hydrogen Sulfide}

Hydrogen sulfide $\left(\mathrm{H}_{2} \mathrm{~S}\right)$ is a colorless, flammable, and water-soluble gas with a very specific smell of rotten eggs [119]. For decades, $\mathrm{H}_{2} \mathrm{~S}$ was perceived only as a toxic pollutant with a negative effect on the environment. However, recent investigations demonstrated that it is enzymatically produced in the human body serving as a gaseous hormone [120].

There are two main pathways of $\mathrm{H}_{2} \mathrm{~S}$ production: either the endogenous pathway driven by the enzymes of human cells or the microbial pathway localized in the gut microbiota. The precursors of $\mathrm{H}_{2} \mathrm{~S}$ synthesis are mainly the sulfur amino acids and the free sulfate. $\mathrm{H}_{2} \mathrm{~S}$ produced in the gut should be considered a candidate postbiotic [121]. The production of $\mathrm{H}_{2} \mathrm{~S}$ was described in the bacterial genera Fusarium, Clostridium, Salmonella, Escherichia, Klebsiella, Streptococcus, Desulfovibrio, Enterobacter and others [122].

\subsection{Biological Effects}

$\mathrm{H}_{2} \mathrm{~S}$ possesses either a cytoprotective or a cytotoxic effect depending on its concentration and the cell type. At low concentrations, it serves as an antioxidant neutralizing various reactive oxygen species and acting additively to the known antioxidants, such as $\mathrm{N}$-acetylcysteine, superoxide dismutase, or glutathione [123]. At high concentrations, $\mathrm{H}_{2} \mathrm{~S}$ binds to the cytochrome c oxidase blocking the electron transport chain and diminishing the synthesis of ATP [115] (Figure 3). It can also initiate the expression of different proapoptotic genes and trigger apoptosis [124]. 


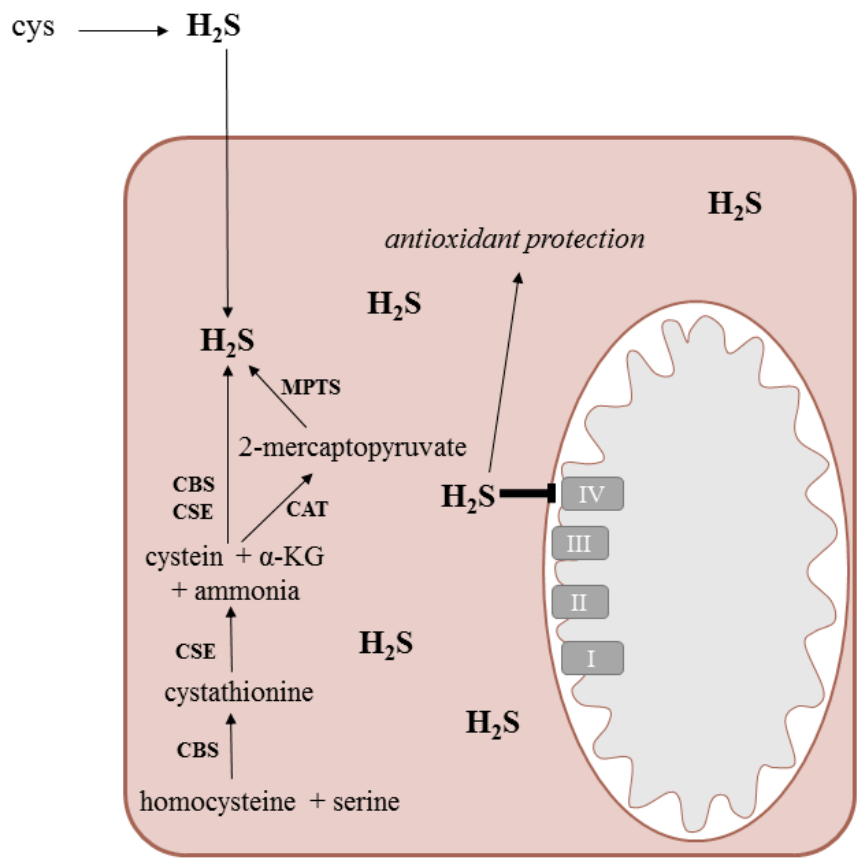

CANCER CELL

Figure 3. Synthesis and metabolism of $\mathrm{H}_{2} \mathrm{~S}$ in the cancer cell $\left(\alpha-\mathrm{KG}\right.$-alpha-ketoglutarate, $\mathrm{H}_{2} \mathrm{~S}-$ hydrogen sulfide, CAT—cysteine: 2-oxoglutarate aminotransferase, CBS—cystathionine beta-synthase, CSE - cystathionine gamma-lyase, cys — cysteine, MPTS—3-mercaptopyruvate sulfurtransferase).

$\mathrm{H}_{2} \mathrm{~S}$ acts mainly through the regulation of mitochondrial bioenergetics including the activation of potassium channels [125], stimulation of signaling kinases [126], and inhibition of phosphodiesterases [127].

\subsection{Role in Cancer}

\subsubsection{Colon Cancer}

Due to the sulfate-reducing bacteria, the concentration of $\mathrm{H}_{2} \mathrm{~S}$ in the colon reaches approximately $0.3-3.4 \mathrm{mmol} \cdot \mathrm{L}^{-1}$ [128]. A high dose of $\mathrm{H}_{2} \mathrm{~S}$ causes a decrease in the proliferation and the induction of the $\mathrm{G}_{0} / \mathrm{G}_{1}$ blockage of the cell cycle resulting, in an overall antimitotic effect. It can also induce autophagy and inhibit the invasion and migration of cancer cells [129]. Its effects, therefore, resemble SCFA.

On the other hand, it was demonstrated that silencing or inhibition of the endogenous enzymes producing $\mathrm{H}_{2} \mathrm{~S}$, often upregulated in tumors, leads to the suppression of the bioenergetics resulting in the reduction of the tumor growth in vivo [130]. In addition, the low doses of exogenous donors of hydrogen sulfide stimulate cell migration via the activation of Akt/PI3K [131].

In 2016, Ianaro et al. summarized the chemopreventive effect of $\mathrm{H}_{2} \mathrm{~S}$-releasing nonsteroidal anti-inflammatory drug (NSAID) ATB-346. They used the aberrant crypt foci (ACF) model of colon cancer. This model is based on the creation of ACF after the administration of carcinogen and untreated lesions are then developing into the tumors. They demonstrated a synergy between NSAID and $\mathrm{H}_{2} \mathrm{~S}$ and the superiority of the combined approach over $\mathrm{H}_{2} \mathrm{~S}$ or NSAID alone in terms of tolerability and efficiency [132].

\subsubsection{Other Tumors}

$\mathrm{H}_{2} \mathrm{~S}$ produced by bacteria freely enters the cells because of its lipophilicity and small size [133]. In 2015, Cakmak published a study pointing at the connection between gut microbiota-produced hydrogen sulfide and Parkinson's disease. He proved that a lower level of the gut bacteria Prevotella negatively affects the progression of Parkinson's disease. This was probably due to the gut-brain axis [134]. Thus, this study shows that as a 
postbiotic, hydrogen sulfide can affect different tissues, not only the bowel, suggesting that this gas could also affect other types of cancer.

The sign of impaired $\mathrm{H}_{2} \mathrm{~S}$ metabolism is the accumulation of metabolic byproducts thiosulfate or sulfite. These metabolites are excreted via urine, and higher levels are associated with prostate cancer. There is also a positive correlation between the level of thiosulfate and the tumor volume $[119,135]$.

In contrast, Liu et al. summarized the effects of different $\mathrm{H}_{2} \mathrm{~S}$-releasing donors in the prostate cancer cell line PC-3. They demonstrated that sodium sulfide is a rapidly releasing donor of $\mathrm{H}_{2} \mathrm{~S}$ that significantly decreases cell viability, reduces the rate of growth, and decreases cell clonogenicity $[136,137]$. Diallyl disulfide and diallyl trisulfide, the sulfidebased metabolites of garlic, compromise cell survival and induce the apoptosis in PC-3 line $[138,139]$. In addition, sulforaphane from the cruciferous vegetable (broccoli) also triggers apoptosis and reduces the growth of tumors by acting as an antiproliferative agent [140]. In general, numerous other exogenous $\mathrm{H}_{2} \mathrm{~S}$ donors administered in relatively high doses manifested anticancer effects in vitro and in vivo [141,142].

Therefore, $\mathrm{H}_{2} \mathrm{~S}$ is a postbiotics acting as a double edge sword. While the low levels are cytoprotective in both normal tissue and tumors, the very high levels cause tissue damage, which may be turned into anticancer therapy under certain conditions.

\section{7. $\beta$-Glucans}

The term $\beta$-glucans is used for a group of the glucose polymers consisting of a $(1 \rightarrow 3)$ $\beta$-D-glucopyranosyl chain with randomly dispersed $\beta$-D-glucopyranosyl units attached by a $(1 \rightarrow 6)-\beta$ bond [143]. As a component of dietary fiber, $\beta$-glucans have been found in a variety of plants and microorganisms, including oat, barley, medicinal mushrooms, seaweed, some bacteria, and also yeasts, where they represent an important component of the cell walls $[144,145]$. $\beta$-glucans were identified as biological response modifiers stimulating the immune system to fight cancer 60 years ago [146].

\subsection{Forms of $\beta$-Glucans}

There are two main forms of $\beta$-glucans-the particulate and the soluble. The particulate $\beta$-glucans are administered orally [147]. They are ingested by gastrointestinal macrophages and transported to the spleen and the bone marrow. Because of the absence of glucanase, the macrophages metabolize $\beta$-glucans through an oxidative pathway. The treatment with $\beta$-glucans stimulates the macrophages to secrete the pro-inflammatory cytokines such as TNF $\alpha$ (tumor necrosis factor $\alpha$ ) or IL-6 (interleukin-6) [148].

Soluble $\beta$-glucans are formed by a triple helix of glucose polymer. The helices have a $\beta$-(1-3)-glucan backbones containing $\beta-(1-6)$-linked $\beta$-(1-3) branches. This form of $\beta$ glucans is soluble in water, easy to be purified, and the molecules have an intermediate size [143]. The soluble $\beta$-glucans may be administered intravenously and then metabolized by macrophages [149].

\subsection{Mechanism of Action}

Antibody therapy is effective for patients with a high expression of specific target antigens on the cancer cell surface. $\mathrm{C} 3 \mathrm{~b}$ and $\mathrm{iC} 3 \mathrm{~b}$ are the components of the complementdependent cytotoxic system that contributes significantly to tumor regression. These two components connected with the complement activation in the presence of natural or intravenously injected anti-tumor antibodies are capable of binding to the complement receptor CR3 on neutrophils, macrophages, and natural killer cells triggering the phagocytosis and cytotoxic degranulation. Unfortunately, this reaction is hindered by the absence of a non-specific co-stimulation with microbial biopolymers, normally present during the antibacterial response. However, the presence of $\beta$-glucans may serve as the co-stimulator triggering the tumoricidal activity of the innate immune system [150,151].

$\mathrm{CR} 3$ receptor can recognize $\mathrm{iC} 3$ via the $\mathrm{CD} 11 \mathrm{~b} \mathrm{I}$-domain binding site on the $\mathrm{N}$-terminus and the specific microbial polysaccharides via a lectin site located on the $C$-terminus. $\beta$ - 
glucans bind to the lectin site, thus priming the immune cells to kill iC3b-coated tumor cells [152] (Figure 4).

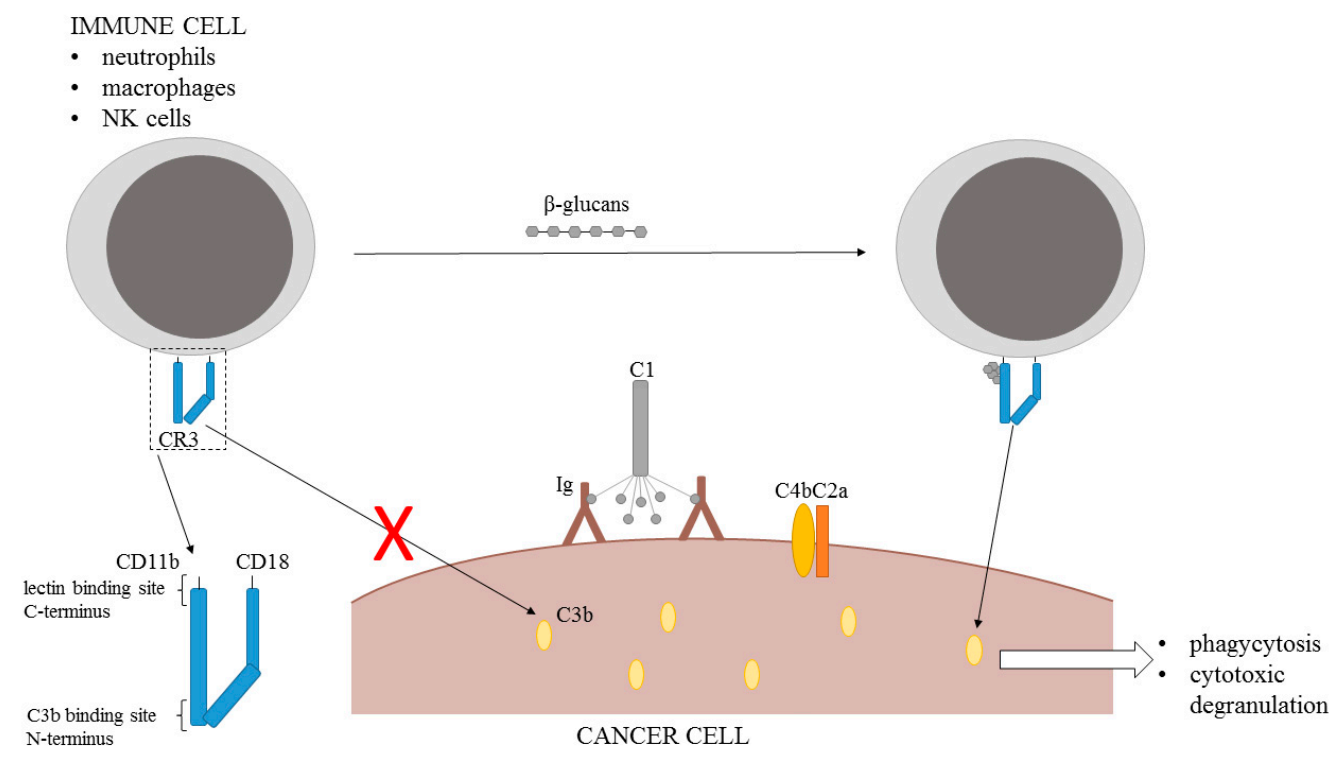

Figure 4. Mechanism of $\beta$-glucans action (CD—complement domain, $C R$ —complement receptor, Ig-immunoglobulin).

A number of in vitro and in vivo studies pointed to this feature of $\beta$ glucans $[143,146,151,153]$. It has been demonstrated that $\beta$-glucans must be administered orally because intravenously administered glucans are rapidly scavenged by CR3 blood granulocytes and liver Kupffer cells, and only a small amount of glucans reaches the tissue macrophages that could migrate into tumors [154]. The study of Hong et al., using five mice tumor models, showed that tumor regression and animal survival were significantly enhanced in a group of mice receiving the combination therapy of monoclonal antitumor antibodies and $\beta$-glucans [151]. The therapy was successful only upon the natural antibody administration in the case of a mouse model with inherited severe combined immunodeficiency. Moreover, the therapy failed in C3-deficient mice. On the other hand, the study of Yang et al. discovered that $\beta$-glucans are effective even as a monotherapy in the presence of naturally occurring antitumor antibodies [155].

While $\beta$-glucans may also serve as prebiotics with anti-inflammatory properties $[155,156]$, their direct immunity-stimulating postbiotic role will gain further attention due to the rising importance of cancer immunotherapy.

\section{Conclusions}

Postbiotics represent an emerging concept appreciating the importance of microbial metabolites in the maintenance of health. Butyrate, the prototypical SCFA, derived from the intestinal metabolism of fiber or supplemented as tributyrin inhibits carcinogenesis and selectively induces apoptosis in tumor cells. Lactate produced by LAB in fermented food or the gut serves as a signaling molecule in the host. It may inhibit early carcinogenesis by its anti-inflammatory and mitohormetic effects. However, the endogenously produced lactate is an important contributor to cancer progression. Therefore, LAB-fermented food is an important part of a cancer-preventing diet, but the application of lactate in the anticancer therapy is unlikely. Hydrogen sulfide is also a double-edged sword in the fight against cancer. While its endogenous moderate production is indispensable for cancer cell survival, the consumption of high-dose $\mathrm{H}_{2} \mathrm{~S}$ donors, especially those of plant origin, is an emerging anticancer strategy. The broad family of $\beta$-glucans is well known for its immunomodulatory properties. The accumulating body of evidence demonstrates the utility of $\beta$-glucans co-treatment during anticancer immunotherapy. Taken together, the 
molecules inspired by microbiota-derived functional metabolites represent a novel and promising class of remedies applicable in cancer prevention and treatment.

Funding: This work was supported by grant no. 21-11688S given by the Czech Science Foundation and by the Specific University Research grant given by the Czech Ministry of Education (MSMT No 21-SVV /2019).

Institutional Review Board Statement: Not applicable.

Informed Consent Statement: Not applicable.

Data Availability Statement: Not applicable.

Conflicts of Interest: The authors declare no conflict of interest.

\section{References}

1. Qin, J.; Li, R.; Raes, J.; Arumugam, M.; Burgdorf, K.S.; Manichanh, C.; Nielsen, T.; Pons, N.; Levenez, F.; Yamada, T.; et al. A human gut microbial gene catalogue established by metagenomic sequencing. Nature 2010, 464, 59-65. [CrossRef]

2. Bäckhed, F.; Ley, R.E.; Sonnenburg, J.L.; Peterson, D.A.; Gordon, J.I. Host-bacterial mutualism in the human intestine. Science 2005, 307, 1915-1920. [CrossRef] [PubMed]

3. Karasov, W.H.; Martínez del Rio, C.; Caviedes-Vidal, E. Ecological physiology of diet and digestive systems. Annu. Rev. Physiol. 2011, 73, 69-93. [CrossRef]

4. Claus, S.P.; Guillou, H.; Ellero-Simatos, S. The gut microbiota: A major player in the toxicity of environmental pollutants? NPJ Biofilms Microbiomes 2016, 2, 16003. [CrossRef] [PubMed]

5. LeBlanc, J.G.; Milani, C.; de Giori, G.S.; Sesma, F.; van Sinderen, D.; Ventura, M. Bacteria as vitamin suppliers to their host: A gut microbiota perspective. Curr. Opin. Biotechnol. 2013, 24, 160-168. [CrossRef]

6. Hooper, L.V.; Littman, D.R.; Macpherson, A.J. Interactions between the microbiota and the immune system. Science 2012, 336, 1268-1273. [CrossRef]

7. Żółkiewicz, J.; Marzec, A.; Ruszczyński, M.; Feleszko, W. Postbiotics-A Step Beyond Pre- and Probiotics. Nutrients 2020, $12,2189$. [CrossRef]

8. Wikoff, W.R.; Anfora, A.T.; Liu, J.; Schultz, P.G.; Lesley, S.A.; Peters, E.C.; Siuzdak, G. Metabolomics analysis reveals large effects of gut microflora on mammalian blood metabolites. Proc. Natl. Acad. Sci. USA 2009, 106, 3698-3703. [CrossRef]

9. Sartor, R.B. Gut microbiota: Diet promotes dysbiosis and colitis in susceptible hosts. Nat. Rev. Gastroenterol. Hepatol. 2012, 9, 561-562. [CrossRef] [PubMed]

10. Tlaskalová-Hogenová, H.; Stěpánková, R.; Kozáková, H.; Hudcovic, T.; Vannucci, L.; Tučková, L.; Rossmann, P.; Hrnčíř, T.; Kverka, M.; Zákostelská, Z.; et al. The role of gut microbiota (commensal bacteria) and the mucosal barrier in the pathogenesis of inflammatory and autoimmune diseases and cancer: Contribution of germ-free and gnotobiotic animal models of human diseases. Cell. Mol. Immunol. 2011, 8, 110-120. [CrossRef] [PubMed]

11. Tsilingiri, K.; Barbosa, T.; Penna, G.; Caprioli, F.; Sonzogni, A.; Viale, G.; Rescigno, M. Probiotic and postbiotic activity in health and disease: Comparison on a novel polarised ex-vivo organ culture model. Gut 2012, 61, 1007-1015. [CrossRef] [PubMed]

12. Escamilla, J.; Lane, M.; Maitin, V. Cell-Free Supernatants from Probiotic Lactobacillus casei and Lactobacillus rhamnosus GG Decrease Colon Cancer Cell Invasion In Vitro. Nutr. Cancer 2012, 64, 871-878. [CrossRef] [PubMed]

13. Sauer, J.; Richter, K.K.; Pool-Zobel, B.L. Physiological concentrations of butyrate favorably modulate genes of oxidative and metabolic stress in primary human colon cells. J. Nutr. Biochem. 2007, 18, 736-745. [CrossRef] [PubMed]

14. Abrahamse, S.L.; Pool-Zobel, B.L.; Rechkemmer, G. Potential of short chain fatty acids to modulate the induction of DNA damage and changes in the intracellular calcium concentration by oxidative stress in isolated rat distal colon cells. Carcinogenesis 1999, 20, 629-634. [CrossRef]

15. Hague, A.; Paraskeva, C. The short-chain fatty acid butyrate induces apoptosis in colorectal tumour cell lines. Eur. J. Cancer Prev. 1995, 4, 359-364. [CrossRef]

16. Hague, A.; Elder, D.J.; Hicks, D.J.; Paraskeva, C. Apoptosis in colorectal tumour cells: Induction by the short chain fatty acids butyrate, propionate and acetate and by the bile salt deoxycholate. Int. J. Cancer 1995, 60, 400-406. [CrossRef]

17. Śliżewska, K.; Markowiak-Kopeć, P.; Śliżewska, W. The Role of Probiotics in Cancer Prevention. Cancers 2020, 13, 13. [CrossRef]

18. Dos Reis, S.A.; da Conceição, L.L.; Siqueira, N.P.; Rosa, D.D.; da Silva, L.L.; Peluzio, M.D. Review of the mechanisms of probiotic actions in the prevention of colorectal cancer. Nutr. Res. 2017, 37, 1-19. [CrossRef]

19. Perillo, F.; Amoroso, C.; Strati, F.; Giuffrè, M.R.; Díaz-Basabe, A.; Lattanzi, G.; Facciotti, F. Gut Microbiota Manipulation as a Tool for Colorectal Cancer Management: Recent Advances in Its Use for Therapeutic Purposes. Int. J. Mol. Sci. 2020, 21, 5389. [CrossRef]

20. Cheng, Y.; Ling, Z.; Li, L. The Intestinal Microbiota and Colorectal Cancer. Front. Immunol. 2020, 11, 615056. [CrossRef]

21. Ding, S.; Hu, C.; Fang, J.; Liu, G. The Protective Role of Probiotics against Colorectal Cancer. Oxid. Med. Cell. Longev. 2020, 2020, 8884583. [CrossRef] 
22. Fong, W.; Li, Q.; Yu, J. Gut microbiota modulation: A novel strategy for prevention and treatment of colorectal cancer. Oncogene 2020, 39, 4925-4943. [CrossRef] [PubMed]

23. Zelenka, J.; Koncošová, M.; Ruml, T. Targeting of stress response pathways in the prevention and treatment of cancer. Biotechnol. Adv. 2018, 36, 583-602. [CrossRef]

24. Wang, W.; Fang, D.; Zhang, H.; Wangchuk, D.; Du, J.; Jiang, L. Sodium butyrate selectively kills cancer cells and inhibits migration in colorectal cancer by targeting thioredoxin-1. Oncotargets Ther. 2020, 13, 4691-4704. [CrossRef] [PubMed]

25. Cao, X.; Xie, Z.; Yang, Y.; Whiteman, M.; Moore, P.K.; Bian, J. A review of hydrogen sulfide synthesis, metabolism, and measurment: Is modulation of hydrogen sulfide a novel therapeutic for cancer? Antioxid. Redox Signal. 2019, 31, 1-38. [CrossRef] [PubMed]

26. Fay, J.R.; Steele, V.; Crowell, J.A. Energy homeostasis and cancer prevention: The AMP-activated protein kinase. Cancer Prev. Res. 2009, 2, 301-309. [CrossRef]

27. Wang, N.; Liu, H.; Liu, G.; Li, M.; He, X.; Yin, C.; Tu, Q.; Shen, X.; Bai, W.; Wang, Q.; et al. Yeast $\beta$-glucan exerts antitumour activity in liver cancer through impairing autophagy and lysosomal function, promoting reactive oxygen species production and apoptosis. Redox Biol. 2020, 32, 101495. [CrossRef]

28. Zhang, W.; Feng, Y.; Guo, Q.; Xu, H.; Li, X.; Guan, Y.; Geng, N.; Wang, P.; Cao, L.; O’Rouke, B.P.; et al. SIRT1 modulates cell cycle progression by regulating CHK2 acetylation-phosphorylation. Cell Death Differ. 2020, 27, 482-496. [CrossRef]

29. Sun, B.; Jia, Y.; Yang, S.; Zhao, N.; Hu, Y.; Hong, J.; Gao, S.; Zhao, R. Sodium butyrate protects against high-fat diet-induced oxidative stress in rat liver by promoting expression of nuclear factor E2-related factor 2. Br. J. Nutr. 2019, 122, 400-410. [CrossRef]

30. Bahmani, S.; Azarpira, N.; Moazamian, E. Anti-colon cancer activity of Bifidobacterium metabolites on colon cancer cell line SW742. Turk. J. Gastroenterol. 2019, 30, 835-842. [CrossRef]

31. Kim, Y.; Lee, D.; Kim, D.; Cho, J.; Yang, J.; Chung, M.; Kim, K.; Ha, N. Inhibition of proliferation in colon cancer cell lines and harmful enzyme activity of colon bacteria by Bifidobacterium adolescentis SPM0212. Arch. Pharm. Res. 2008, 31, 468-473. [CrossRef] [PubMed]

32. Leeman, M.F.; Curran, S.; Murray, G.I. New insights into the roles of matrix metalloproteinases in colorectal cancer development and progression. J. Pathol. 2003, 201, 528-534. [CrossRef] [PubMed]

33. Yu, Q.H.; Yang, Q. Diversity of tight junctions (TJs) between gastrointestinal epithelial cells and their function in maintaining the mucosal barrier. Cell Biol. Int. 2009, 33, 78-82. [CrossRef] [PubMed]

34. Yue, Y.; Ye, K.; Lu, J.; Wang, X.; Zhang, S.; Liu, L.; Yang, B.; Nassar, K.; Xu, X.; Pang, X.; et al. Probiotic strain Lactobacillus plantarum YYC-3 prevents colon cancer in mice by regulating the tumour microenvironment. Biomed. Pharmacother. 2020, 127, 110159. [CrossRef] [PubMed]

35. An, J.; Ha, E.M. Combination Therapy of Lactobacillus plantarum Supernatant and 5-Fluouracil Increases Chemosensitivity in Colorectal Cancer Cells. J. Microbiol. Biotechnol. 2016, 26, 1490-1503. [CrossRef] [PubMed]

36. Topping, D.L.; Clifton, P.M. Short-chain fatty acids and human colonic function: Roles of resistant starch and nonstarch polysaccharides. Physiol. Rev. 2001, 81, 1031-1064. [CrossRef]

37. Bergman, E.N. Energy contributions of volatile fatty acids from the gastrointestinal tract in various species. Physiol. Rev. 1990, 70, 567-590. [CrossRef]

38. Bultman, S.J. Molecular pathways: Gene-environment interactions regulating dietary fiber induction of proliferation and apoptosis via butyrate for cancer prevention. Clin. Cancer Res. 2014, 20, 799-803. [CrossRef]

39. Ahmad, M.S.; Krishnan, S.; Ramakrishna, B.S.; Mathan, M.; Pulimood, A.B.; Murthy, S.N. Butyrate and glucose metabolism by colonocytes in experimental colitis in mice. Gut 2000, 46, 493-499. [CrossRef]

40. Chen, H.M.; Yu, Y.N.; Wang, J.L.; Lin, Y.W.; Kong, X.; Yang, C.Q.; Yang, L.; Liu, Z.J.; Yuan, Y.Z.; Liu, F.; et al. Decreased dietary fiber intake and structural alteration of gut microbiota in patients with advanced colorectal adenoma. Am. J. Clin. Nutr. 2013, 97, 1044-1052. [CrossRef]

41. Charney, A.N.; Micic, L.; Egnor, R.W. Nonionic diffusion of short-chain fatty acids across rat colon. Am. J. Physiol. 1998, 274, G518-G524. [CrossRef]

42. Hadjiagapiou, C.; Schmidt, L.; Dudeja, P.K.; Layden, T.J.; Ramaswamy, K. Mechanism(s) of butyrate transport in Caco-2 cells: Role of monocarboxylate transporter 1. Am. J. Physiol. Gastrointest. Liver Physiol. 2000, 279, G775-G780. [CrossRef]

43. Ganapathy, V.; Thangaraju, M.; Prasad, P.D.; Martin, P.M.; Singh, N. Transporters and receptors for short-chain fatty acids as the molecular link between colonic bacteria and the host. Curr. Opin. Pharmacol. 2013, 13, 869-874. [CrossRef]

44. Cuff, M.; Dyer, J.; Jones, M.; Shirazi-Beechey, S. The human colonic monocarboxylate transporter Isoform 1: Its potential importance to colonic tissue homeostasis. Gastroenterology 2005, 128, 676-686. [CrossRef] [PubMed]

45. Thibault, R.; De Coppet, P.; Daly, K.; Bourreille, A.; Cuff, M.; Bonnet, C.; Mosnier, J.F.; Galmiche, J.P.; Shirazi-Beechey, S.; Segain, J.P. Down-regulation of the monocarboxylate transporter 1 is involved in butyrate deficiency during intestinal inflammation. Gastroenterology 2007, 133, 1916-1927. [CrossRef] [PubMed]

46. Lambert, D.W.; Wood, I.S.; Ellis, A.; Shirazi-Beechey, S.P. Molecular changes in the expression of human colonic nutrient transporters during the transition from normality to malignancy. Br. J. Cancer 2002, 86, 1262-1269. [CrossRef]

47. Koukourakis, M.I.; Giatromanolaki, A.; Harris, A.L.; Sivridis, E. Comparison of metabolic pathways between cancer cells and stromal cells in colorectal carcinomas: A metabolic survival role for tumor-associated stroma. Cancer Res. 2006, 66, 632-637. [CrossRef] 
48. Heidor, R.; Ortega, J.F.; de Conti, A.; Ong, T.P.; Moreno, F.S. Anticarcinogenic actions of tributyrin, a butyric acid prodrug. Curr. Drug Targets 2012, 13, 1720-1729. [CrossRef]

49. Gupta, N.; Martin, P.M.; Prasad, P.D.; Ganapathy, V. SLC5A8 (SMCT1)-mediated transport of butyrate forms the basis for the tumor suppressive function of the transporter. Life Sci. 2006, 78, 2419-2425. [CrossRef]

50. Borthakur, A.; Anbazhagan, A.N.; Kumar, A.; Raheja, G.; Singh, V.; Ramaswamy, K.; Dudeja, P.K. The probiotic Lactobacillus plantarum counteracts TNF-\{alpha\}-induced downregulation of SMCT1 expression and function. Am. J. Physiol. Gastrointest. Liver Physiol. 2010, 299, G928-G934. [CrossRef]

51. Ganapathy, V.; Thangaraju, M.; Gopal, E.; Martin, P.; Itagaki, S.; Miyauchi, S.; Prasad, P. Sodium-coupled Monocarboxylate Transporters in Normal Tissues and in Cancer. AAPS J. 2008, 10, 193-199. [CrossRef]

52. Doshi, M.; Takiue, Y.; Saito, H.; Hosoyamada, M. The Increased Protein Level of URAT1 was Observed in Obesity/Metabolic Syndrome Model Mice. Nucleosides Nucleotides Nucleic Acids 2011, 30, 1290-1294. [CrossRef] [PubMed]

53. Whitman, S.P.; Hackanson, B.; Liyanarachchi, S.; Liu, S.; Rush, L.J.; Maharry, K.; Margeson, D.; Davuluri, R.; Wen, J.; Witte, T.; et al. DNA hypermethylation and epigenetic silencing of the tumor suppressor gene, SLC5A8, in acute myeloid leukemia with the MLL partial tandem duplication. Blood 2008, 112, 2013-2016. [CrossRef]

54. Dohgen, M.; Hayahshi, H.; Yajima, T.; Suzuki, Y. Stimulation of Bicarbonate Secretion by Luminal Short-Chain Fatty Acid in the Rat and Human Colon In Vitro. Jpn. J. Physiol. 1994, 44, 519-531. [CrossRef] [PubMed]

55. Dietrich, C.G.; Vehr, A.-K.; Martin, I.V.; Gaßler, N.; Rath, T.; Roeb, E.; Schmitt, J.; Trautwein, C.; Geier, A. Downregulation of breast cancer resistance protein in colon adenomas reduces cellular xenobiotic resistance and leads to accumulation of a food-derived carcinogen. Int. J. Cancer 2011, 129, 546-552. [CrossRef] [PubMed]

56. Gupta, N.; Martin, P.M.; Miyauchi, S.; Ananth, S.; Herdman, A.V.; Martindale, R.G.; Podolsky, R.; Ganapathy, V. Down-regulation of BCRP/ABCG2 in colorectal and cervical cancer. Biochem. Biophys. Res. Commun. 2006, 343, 571-577. [CrossRef]

57. Liu, H.G.; Pan, Y.F.; You, J.; Wang, O.C.; Huang, K.T.; Zhang, X.H. Expression of ABCG2 and its significance in colorectal cancer. Asian Pac. J. Cancer Prev. 2010, 11, 845-848. [PubMed]

58. Nakanishi, T.; Ross, D.D. Breast cancer resistance protein (BCRP/ABCG2): Its role in multidrug resistance and regulation of its gene expression. Chin. J. Cancer 2012, 31, 73-99. [CrossRef]

59. Nakamura, S.; Haga, S.; Kimura, K.; Matsuyama, S. Propionate and butyrate induce gene expression of monocarboxylate transporter 4 and cluster of differentiation 147 in cultured rumen epithelial cells derived from preweaning dairy calves. J. Anim. Sci. 2018, 96, 4902-4911. [CrossRef]

60. Gonçalves, P.; Martel, F. Butyrate and colorectal cancer: The role of butyrate transport. Curr. Drug. Metab. 2013, 14, 994-1008. [CrossRef]

61. Hamer, H.M.; Jonkers, D.; Venema, K.; Vanhoutvin, S.; Troost, F.J.; Brummer, R.J. Review article: The role of butyrate on colonic function. Aliment. Pharmacol. Ther. 2008, 27, 104-119. [CrossRef]

62. Donohoe, D.R.; Garge, N.; Zhang, X.; Sun, W.; O'Connell, T.M.; Bunger, M.K.; Bultman, S.J. The microbiome and butyrate regulate energy metabolism and autophagy in the mammalian colon. Cell Metab. 2011, 13, 517-526. [CrossRef]

63. Donohoe, D.R.; Collins, L.B.; Wali, A.; Bigler, R.; Sun, W.; Bultman, S.J. The Warburg effect dictates the mechanism of butyratemediated histone acetylation and cell proliferation. Mol. Cell 2012, 48, 612-626. [CrossRef]

64. Burgess, D.J. Warburg behind the butyrate paradox? Nat. Rev. Cancer 2012, 12, 798-799. [CrossRef]

65. Davie, J.R. Inhibition of histone deacetylase activity by butyrate. J. Nutr. 2003, 133, 2485s-2493s. [CrossRef] [PubMed]

66. Sengupta, S.; Muir, J.G.; Gibson, P.R. Does butyrate protect from colorectal cancer? J. Gastroenterol. Hepatol. 2006, 21, 209-218. [CrossRef] [PubMed]

67. Rosignoli, P.; Fabiani, R.; De Bartolomeo, A.; Spinozzi, F.; Agea, E.; Pelli, M.A.; Morozzi, G. Protective activity of butyrate on hydrogen peroxide-induced DNA damage in isolated human colonocytes and HT29 tumour cells. Carcinogenesis 2001, 22, 1675-1680. [CrossRef]

68. Pool-Zobel, B.L.; Selvaraju, V.; Sauer, J.; Kautenburger, T.; Kiefer, J.; Richter, K.K.; Soom, M.; Wölfl, S. Butyrate may enhance toxicological defence in primary, adenoma and tumor human colon cells by favourably modulating expression of glutathione S-transferases genes, an approach in nutrigenomics. Carcinogenesis 2005, 26, 1064-1076. [CrossRef]

69. Stein, J.; Schröder, O.; Bonk, M.; Oremek, G.; Lorenz, M.; Caspary, W.F. Induction of glutathione-S-transferase-pi by short-chain fatty acids in the intestinal cell line Caco-2. Eur. J. Clin. Investig. 1996, 26, 84-87. [CrossRef] [PubMed]

70. Ebert, M.N.; Klinder, A.; Peters, W.H.; Schäferhenrich, A.; Sendt, W.; Scheele, J.; Pool-Zobel, B.L. Expression of glutathione S-transferases (GSTs) in human colon cells and inducibility of GSTM2 by butyrate. Carcinogenesis 2003, 24, 1637-1644. [CrossRef]

71. Liu, E.Y.; Ryan, K.M. Autophagy and cancer-issues we need to digest. J. Cell Sci. 2012, 125, 2349-2358. [CrossRef]

72. Luo, S.; Li, Z.; Mao, L.; Chen, S.; Sun, S. Sodium butyrate induces autophagy in colorectal cancer cells through LKB1/AMPK signaling. J. Physiol. Biochem. 2019, 75, 53-63. [CrossRef]

73. Zhang, J.; Yi, M.; Zha, L.; Chen, S.; Li, Z.; Li, C.; Gong, M.; Deng, H.; Chu, X.; Chen, J.; et al. Sodium Butyrate Induces Endoplasmic Reticulum Stress and Autophagy in Colorectal Cells: Implications for Apoptosis. PLoS ONE 2016, 11, e0147218. [CrossRef]

74. Sawada, N. Tight junction-related human diseases. Pathol. Int. 2013, 63, 1-12. [CrossRef]

75. Lester, B.R.; McCarthy, J.B. Tumor cell adhesion to the extracellular matrix and signal transduction mechanisms implicated in tumor cell motility, invasion and metastasis. Cancer Metastasis Rev. 1992, 11, 31-44. [CrossRef]

76. Rudzki, Z.; Jothy, S. CD44 and the adhesion of neoplastic cells. Mol. Pathol. 1997, 50, 57-71. [CrossRef] 
77. Zeng, H.; Briske-Anderson, M. Prolonged butyrate treatment inhibits the migration and invasion potential of HT1080 tumor cells. J. Nutr. 2005, 135, 291-295. [CrossRef]

78. Barshishat, M.; Levi, I.; Benharroch, D.; Schwartz, B. Butyrate down-regulates CD44 transcription and liver colonisation in a highly metastatic human colon carcinoma cell line. Br. J. Cancer 2002, 87, 1314-1320. [CrossRef]

79. Cousin, F.J.; Jouan-Lanhouet, S.; Dimanche-Boitrel, M.-T.; Corcos, L.; Jan, G. Milk fermented by Propionibacterium freudenreichii induces apoptosis of HGT-1 human gastric cancer cells. PLoS ONE 2012, 7, e31892. [CrossRef]

80. Hague, A.; Manning, A.M.; Hanlon, K.A.; Huschtscha, L.I.; Hart, D.; Paraskeva, C. Sodium butyrate induces apoptosis in human colonic tumour cell lines in a p53-independent pathway: Implications for the possible role of dietary fibre in the prevention of large-bowel cancer. Int. J. Cancer 1993, 55, 498-505. [CrossRef]

81. Chirakkal, H.; Leech, S.H.; Brookes, K.E.; Prais, A.L.; Waby, J.S.; Corfe, B.M. Upregulation of BAK by butyrate in the colon is associated with increased Sp3 binding. Oncogene 2006, 25, 7192-7200. [CrossRef]

82. Watkins, S.M.; Carter, L.C.; Mak, J.; Tsau, J.; Yamamoto, S.; German, J.B. Butyric acid and tributyrin induce apoptosis in human hepatic tumour cells. J. Dairy Res. 1999, 66, 559-567. [CrossRef]

83. Maier, S.; Reich, E.; Martin, R.; Bachem, M.; Altug, V.; Hautmann, R.E.; Gschwend, J.E. Tributyrin induces differentiation, growth arrest and apoptosis in androgen-sensitive and androgen-resistant human prostate cancer cell lines. Int. J. Cancer 2000, 88, 245-251. [CrossRef]

84. Yan, J.; Xu, Y.-H. Tributyrin inhibits human gastric cancer SGC-7901 cell growth by inducing apoptosis and DNA synthesis arrest. World J. Gastroenterol. 2003, 9, 660-664. [CrossRef]

85. Giermasz, A.; Nowis, D.; Jalili, A.; Basak, G.; Marczak, M.; Makowski, M.; Czajka, A.; Młynarczuk, I.; Hoser, G.; Stok osa, T.; et al. Antitumor activity of tributyrin in murine melanoma model. Cancer Lett. 2001, 164, 143-148. [CrossRef]

86. Kuefer, R.; Hofer, M.D.; Altug, V.; Zorn, C.; Genze, F.; Kunzi-Rapp, K.; Hautmann, R.E.; Gschwend, J.E. Sodium butyrate and tributyrin induce in vivo growth inhibition and apoptosis in human prostate cancer. Br. J. Cancer 2004, 90, 535-541. [CrossRef] [PubMed]

87. Edelman, M.J.; Bauer, K.; Khanwani, S.; Tait, N.; Trepel, J.; Karp, J.; Nemieboka, N.; Chung, E.-J.; Van Echo, D. Clinical and pharmacologic study of tributyrin: An oral butyrate prodrug. Cancer Chemother. Pharmacol. 2003, 51, 439-444. [CrossRef]

88. Kuroiwa-Trzmielina, J.; de Conti, A.; Scolastici, C.; Pereira, D.; Horst, M.A.; Purgatto, E.; Ong, T.P.; Moreno, F.S. Chemoprevention of rat hepatocarcinogenesis with histone deacetylase inhibitors: Efficacy of tributyrin, a butyric acid prodrug. Int. J. Cancer 2009, 124, 2520-2527. [CrossRef]

89. Glueck, B.; Han, Y.; Cresci, G.A.M. Tributyrin Supplementation Protects Immune Responses and Vasculature and Reduces Oxidative Stress in the Proximal Colon of Mice Exposed to Chronic-Binge Ethanol Feeding. J. Immunol. Res. 2018, 2018, 9671919. [CrossRef] [PubMed]

90. Cresci, G.; Nagy, L.E.; Ganapathy, V. Lactobacillus GG and tributyrin supplementation reduce antibiotic-induced intestinal injury. JPEN J. Parenter. Enter. Nutr. 2013, 37, 763-774. [CrossRef]

91. Halestrap, A.P.; Price, N.T. The proton-linked monocarboxylate transporter (MCT) family: Structure, function and regulation. Biochem. J. 1999, 343 Pt 2, 281-299. [CrossRef]

92. Halestrap, A.P. The SLC16 gene family—structure, role and regulation in health and disease. Mol. Asp. Med. 2013, 34, 337-349. [CrossRef] [PubMed]

93. Halestrap, A.P. The monocarboxylate transporter family-Structure and functional characterization. IUBMB Life 2012, 64, 1-9. [CrossRef]

94. Ganapathy, V.; Gopal, E.; Miyauchi, S.; Prasad, P.D. Biological functions of SLC5A8, a candidate tumour suppressor. Biochem. Soc. Trans. 2005, 33, 237-240. [CrossRef] [PubMed]

95. Srinivas, S.R.; Gopal, E.; Zhuang, L.; Itagaki, S.; Martin, P.M.; Fei, Y.J.; Ganapathy, V.; Prasad, P.D. Cloning and functional identification of slc5a12 as a sodium-coupled low-affinity transporter for monocarboxylates (SMCT2). Biochem. J. 2005, 392, 655-664. [CrossRef]

96. Brooks, G.A. Lactate as a fulcrum of metabolism. Redox Biol. 2020, 35, 101454. [CrossRef]

97. Roland, C.L.; Arumugam, T.; Deng, D.; Liu, S.H.; Philip, B.; Gomez, S.; Burns, W.R.; Ramachandran, V.; Wang, H.; CruzMonserrate, Z.; et al. Cell Surface Lactate Receptor GPR81 Is Crucial for Cancer Cell Survival. Cancer Res. 2014, 74, 5301-5310. [CrossRef]

98. de Bari, L.; Atlante, A. Including the mitochondrial metabolism of L-lactate in cancer metabolic reprogramming. Cell. Mol. Life Sci. 2018, 75, 2763-2776. [CrossRef]

99. Yang, X.; Lu, Y.; Hang, J.; Zhang, J.; Zhang, T.; Huo, Y.; Liu, J.; Lai, S.; Luo, D.; Wang, L.; et al. Lactate-Modulated Immunosuppression of Myeloid-Derived Suppressor Cells Contributes to the Radioresistance of Pancreatic Cancer. Cancer Immunol. Res. 2020, 8, 1440-1451. [CrossRef] [PubMed]

100. Raychaudhuri, D.; Bhattacharya, R.; Sinha, B.P.; Liu, C.S.C.; Ghosh, A.R.; Rahaman, O.; Bandopadhyay, P.; Sarif, J.; D’Rozario, R.; Paul, S.; et al. Lactate Induces Pro-tumor Reprogramming in Intratumoral Plasmacytoid Dendritic Cells. Front. Immunol. 2019, 10, 1878. [CrossRef] [PubMed]

101. Brown, T.P.; Bhattacharjee, P.; Ramachandran, S.; Sivaprakasam, S.; Ristic, B.; Sikder, M.O.F.; Ganapathy, V. The lactate receptor GPR81 promotes breast cancer growth via a paracrine mechanism involving antigen-presenting cells in the tumor microenvironment. Oncogene 2020, 39, 3292-3304. [CrossRef] 
102. Hashimoto, T.; Hussien, R.; Oommen, S.; Gohil, K.; Brooks, G.A. Lactate sensitive transcription factor network in L6 cells: Activation of MCT1 and mitochondrial biogenesis. FASEB J. 2007, 21, 2602-2612. [CrossRef] [PubMed]

103. Zelenka, J.; Dvořák, A.; Alán, L. L-Lactate Protects Skin Fibroblasts against Aging-Associated Mitochondrial Dysfunction via Mitohormesis. Oxid. Med. Cell. Longev. 2015, 2015, 351698. [CrossRef]

104. Tauffenberger, A.; Fiumelli, H.; Almustafa, S.; Magistretti, P.J. Lactate and pyruvate promote oxidative stress resistance through hormetic ROS signaling. Cell Death Dis. 2019, 10, 653. [CrossRef] [PubMed]

105. Walenta, S.; Mueller-Klieser, W.F. Lactate: Mirror and motor of tumor malignancy. Semin. Radiat. Oncol. 2004, 14, 267-274. [CrossRef] [PubMed]

106. Pérez-Tomás, R.; Pérez-Guillén, I. Lactate in the Tumor Microenvironment: An Essential Molecule in Cancer Progression and Treatment. Cancers 2020, 12, 3244. [CrossRef]

107. Hoque, R.; Farooq, A.; Ghani, A.; Gorelick, F.; Mehal, W.Z. Lactate reduces liver and pancreatic injury in Toll-like receptorand inflammasome-mediated inflammation via GPR81-mediated suppression of innate immunity. Gastroenterology 2014, 146, 1763-1774. [CrossRef]

108. Ranganathan, P.; Shanmugam, A.; Swafford, D.; Suryawanshi, A.; Bhattacharjee, P.; Hussein, M.S.; Koni, P.A.; Prasad, P.D.; Kurago, Z.B.; Thangaraju, M.; et al. GPR81, a Cell-Surface Receptor for Lactate, Regulates Intestinal Homeostasis and Protects Mice from Experimental Colitis. J. Immunol. 2018, 200, 1781-1789. [CrossRef]

109. Yang, K.; Xu, J.; Fan, M.; Tu, F.; Wang, X.; Ha, T.; Williams, D.L.; Li, C. Lactate Suppresses Macrophage Pro-Inflammatory Response to LPS Stimulation by Inhibition of YAP and NF-kB Activation via GPR81-Mediated Signaling. Front. Immunol. 2020, 11, 587913. [CrossRef] [PubMed]

110. Huang, Y.; Zhang, J.; Dong, R.; Ji, X.; Jiang, Y.; Cen, J.; Bai, Z.; Hong, K.; Li, H.; Chen, J.; et al. Lactate as a metabolite from probiotic Lactobacilli mitigates ethanol-induced gastric mucosal injury: An in vivo study. BMC Complement. Med. Ther. 2021, 21, 26. [CrossRef] [PubMed]

111. Lee, Y.S.; Kim, T.Y.; Kim, Y.; Lee, S.H.; Kim, S.; Kang, S.W.; Yang, J.Y.; Baek, I.J.; Sung, Y.H.; Park, Y.Y.; et al. Microbiota-Derived Lactate Accelerates Intestinal Stem-Cell-Mediated Epithelial Development. Cell Host Microbe 2018, 24, 833-846.e6. [CrossRef]

112. Larsson, S.C.; Andersson, S.O.; Johansson, J.E.; Wolk, A. Cultured milk, yogurt, and dairy intake in relation to bladder cancer risk in a prospective study of Swedish women and men. Am. J. Clin. Nutr. 2008, 88, 1083-1087. [CrossRef]

113. Bermejo, L.M.; López-Plaza, B.; Santurino, C.; Cavero-Redondo, I.; Gómez-Candela, C. Milk and Dairy Product Consumption and Bladder Cancer Risk: A Systematic Review and Meta-Analysis of Observational Studies. Adv. Nutr. 2019, 10, S224-S238. [CrossRef]

114. Pala, V.; Sieri, S.; Berrino, F.; Vineis, P.; Sacerdote, C.; Palli, D.; Masala, G.; Panico, S.; Mattiello, A.; Tumino, R.; et al. Yogurt consumption and risk of colorectal cancer in the Italian European prospective investigation into cancer and nutrition cohort. Int. J. Cancer 2011, 129, 2712-2719. [CrossRef] [PubMed]

115. Michels, K.B.; Willett, W.C.; Vaidya, R.; Zhang, X.; Giovannucci, E. Yogurt consumption and colorectal cancer incidence and mortality in the Nurses' Health Study and the Health Professionals Follow-Up Study. Am. J. Clin. Nutr. 2020, 112, $1566-1575$. [CrossRef] [PubMed]

116. Kampman, E.; Goldbohm, R.A.; van den Brandt, P.A.; van 't Veer, P. Fermented dairy products, calcium, and colorectal cancer in The Netherlands Cohort Study. Cancer Res. 1994, 54, 3186-3190.

117. Nimptsch, K.; Lee, D.H.; Zhang, X.; Song, M.; Farvid, M.S.; Rezende, L.F.M.; Cao, Y.; Chan, A.T.; Fuchs, C.; Meyerhardt, J.; et al. Dairy intake during adolescence and risk of colorectal adenoma later in life. Br. J. Cancer 2021. [CrossRef] [PubMed]

118. Rifkin, S.B.; Giardiello, F.M.; Zhu, X.; Hylind, L.M.; Ness, R.M.; Drewes, J.L.; Murff, H.J.; Spence, E.H.; Smalley, W.E.; Gills, J.J.; et al. Yogurt consumption and colorectal polyps. Br. J. Nutr. 2020, 124, 80-91. [CrossRef]

119. Liu, M.; Wu, L.; Montaut, S.; Yang, G. Hydrogen Sulfide Signaling Axis as a Target for Prostate Cancer Therapeutics. Prostate Cancer 2016, 2016, 8108549. [CrossRef]

120. Ono, K.; Akaike, T.; Rahaman, M.; Kumagai, Y.; Wink, D.; Tantillo, D.; Hobbs, A.; Nagy, P.; Xian, M.; Lin, J.; et al. The Redox Chemistry and Chemical Biology of H2S, Hydropersulfides and Derived Species: Implications to Their Possible Biological Activity and Utility. Free Radic. Biol. Med. 2014, 77, 82-94. [CrossRef]

121. Medani, M.; Collins, D.; Docherty, N.G.; Baird, A.W.; O'Connell, P.R.; Winter, D.C. Emerging role of hydrogen sulfide in colonic physiology and pathophysiology. Inflamm. Bowel Dis. 2011, 17, 1620-1625. [CrossRef]

122. Tomasova, L.; Konopelski, P.; Ufnal, M. Gut Bacteria and Hydrogen Sulfide: The New Old Players in Circulatory System Homeostasis. Molecules 2016, 21, 1558. [CrossRef]

123. Szabó, C. Hydrogen sulphide and its therapeutic potential. Nat. Rev. Drug Discov. 2007, 6, 917-935. [CrossRef]

124. Zhao, Y.; Biggs, T.D.; Xian, M. Hydrogen sulfide (H2S) releasing agents: Chemistry and biological applications. Chem. Commun. 2014, 50, 11788-11805. [CrossRef] [PubMed]

125. Mustafa, A.K.; Sikka, G.; Gazi, S.K.; Steppan, J.; Jung, S.M.; Bhunia, A.K.; Barodka, V.M.; Gazi, F.K.; Barrow, R.K.; Wang, R.; et al. Hydrogen sulfide as endothelium-derived hyperpolarizing factor sulfhydrates potassium channels. Circ. Res. 2011, 109, 1259-1268. [CrossRef] [PubMed]

126. Cai, W.J.; Wang, M.J.; Moore, P.K.; Jin, H.M.; Yao, T.; Zhu, Y.C. The novel proangiogenic effect of hydrogen sulfide is dependent on Akt phosphorylation. Cardiovasc. Res. 2007, 76, 29-40. [CrossRef] [PubMed] 
127. Coletta, C.; Papapetropoulos, A.; Erdelyi, K.; Olah, G.; Módis, K.; Panopoulos, P.; Asimakopoulou, A.; Gerö, D.; Sharina, I.; Martin, E.; et al. Hydrogen sulfide and nitric oxide are mutually dependent in the regulation of angiogenesis and endothelium-dependent vasorelaxation. Proc. Natl. Acad. Sci. USA 2012, 109, 9161-9166. [CrossRef]

128. Florin, T.; Neale, G.; Gibson, G.R.; Christl, S.U.; Cummings, J.H. Metabolism of dietary sulphate: Absorption and excretion in humans. Gut 1991, 32, 766-773. [CrossRef]

129. Wu, Y.C.; Wang, X.J.; Yu, L.; Chan, F.K.L.; Cheng, A.S.L.; Yu, J.; Sung, J.J.Y.; Wu, W.K.K.; Cho, C.H. Hydrogen sulfide lowers proliferation and induces protective autophagy in colon epithelial cells. PLoS ONE 2012, 7, e37572. [CrossRef]

130. Szabo, C.; Coletta, C.; Chao, C.; Módis, K.; Szczesny, B.; Papapetropoulos, A.; Hellmich, M.R. Tumor-derived hydrogen sulfide, produced by cystathionine- $\beta$-synthase, stimulates bioenergetics, cell proliferation, and angiogenesis in colon cancer. Proc. Natl. Acad. Sci. USA 2013, 110, 12474-12479. [CrossRef]

131. Szabo, C.; Hellmich, M.R. Endogenously produced hydrogen sulfide supports tumor cell growth and proliferation. Cell Cycle 2013, 12, 2915-2916. [CrossRef] [PubMed]

132. Ianaro, A.; Cirino, G.; Wallace, J.L. Hydrogen sulfide-releasing anti-inflammatory drugs for chemoprevention and treatment of cancer. Pharmacol. Res. 2016, 111, 652-658. [CrossRef]

133. Wang, R. Two's company, three's a crowd: Can H2S be the third endogenous gaseous transmitter? FASEB J. 2002, 16, 1792-1798. [CrossRef]

134. Cakmak, Y.O. Provotella-derived hydrogen sulfide, constipation, and neuroprotection in Parkinson's disease. Mov. Disord. 2015, 30, 1151. [CrossRef] [PubMed]

135. Chwatko, G.; Forma, E.; Wilkosz, J.; Głowacki, R.; Jóźwiak, P.; Różański, W.; Bryś, M.; Krześlak, A. Thiosulfate in urine as a facilitator in the diagnosis of prostate cancer for patients with prostate-specific antigen less or equal $10 \mathrm{ng} / \mathrm{mL}$. Clin. Chem. Lab. Med. 2013, 51, 1825-1831. [CrossRef]

136. Pei, Y.; Wu, B.; Cao, Q.; Wu, L.; Yang, G. Hydrogen sulfide mediates the anti-survival effect of sulforaphane on human prostate cancer cells. Toxicol. Appl. Pharmacol. 2011, 257, 420-428. [CrossRef] [PubMed]

137. Duan, F.; Li, Y.; Chen, L.; Zhou, X.; Chen, J.; Chen, H.; Li, R. Sulfur inhibits the growth of androgen-independent prostate cancer in vivo. Oncol. Lett. 2015, 9, 437-441. [CrossRef]

138. Arunkumar, A.; Vijayababu, M.R.; Gunadharini, N.; Krishnamoorthy, G.; Arunakaran, J. Induction of apoptosis and histone hyperacetylation by diallyl disulfide in prostate cancer cell line PC-3. Cancer Lett. 2007, 251, 59-67. [CrossRef]

139. Sielicka-Dudzin, A.; Borkowska, A.; Herman-Antosiewicz, A.; Wozniak, M.; Jozwik, A.; Fedeli, D.; Antosiewicz, J. Impact of JNK1, JNK2, and ligase Itch on reactive oxygen species formation and survival of prostate cancer cells treated with diallyl trisulfide. Eur. J. Nutr. 2012, 51, 573-581. [CrossRef]

140. Chiao, J.W.; Chung, F.L.; Kancherla, R.; Ahmed, T.; Mittelman, A.; Conaway, C.C. Sulforaphane and its metabolite mediate growth arrest and apoptosis in human prostate cancer cells. Int. J. Oncol. 2002, 20, 631-636. [CrossRef]

141. Borkowska, A.; Knap, N.; Antosiewicz, J. Diallyl trisulfide is more cytotoxic to prostate cancer cells PC-3 than to noncancerous epithelial cell line PNT1A: A possible role of p66Shc signaling axis. Nutr. Cancer 2013, 65, 711-717. [CrossRef]

142. Arunkumar, A.; Vijayababu, M.R.; Venkataraman, P.; Senthilkumar, K.; Arunakaran, J. Chemoprevention of rat prostate carcinogenesis by diallyl disulfide, an organosulfur compound of garlic. Biol. Pharm. Bull. 2006, 29, 375-379. [CrossRef] [PubMed]

143. Cheung, N.K.; Modak, S.; Vickers, A.; Knuckles, B. Orally administered beta-glucans enhance anti-tumor effects of monoclonal antibodies. Cancer Immunol. Immunother. 2002, 51, 557-564. [CrossRef] [PubMed]

144. Wasser, S.P.; Weis, A.L. Therapeutic effects of substances occurring in higher Basidiomycetes mushrooms: A modern perspective. Crit. Rev. Immunol. 1999, 19, 65-96. [PubMed]

145. BeMiller, J.A.B.J.N. $(1 \rightarrow 3)-\beta$-d-Glucans as biological response modifiers: A review of structure-functional activity relationships. Carbohydr. Polym. 1995, 28, 3-14.

146. Yan, J.; Vetvicka, V.; Xia, Y.; Coxon, A.; Carroll, M.C.; Mayadas, T.N.; Ross, G.D. Beta-glucan, a "specific" biologic response modifier that uses antibodies to target tumors for cytotoxic recognition by leukocyte complement receptor type 3 (CD11b/CD18). J. Immunol. 1999, 163, 3045-3052. [PubMed]

147. Hong, F.; Yan, J.; Baran, J.T.; Allendorf, D.J.; Hansen, R.D.; Ostroff, G.R.; Xing, P.X.; Cheung, N.K.; Ross, G.D. Mechanism by which orally administered beta-1,3-glucans enhance the tumoricidal activity of antitumor monoclonal antibodies in murine tumor models. J. Immunol. 2004, 173, 797-806. [CrossRef] [PubMed]

148. Li, B.; Cramer, D.; Wagner, S.; Hansen, R.; King, C.; Kakar, S.; Ding, C.; Yan, J. Yeast glucan particles activate murine resident macrophages to secrete proinflammatory cytokines via MyD88- and Syk kinase-dependent pathways. Clin. Immunol. 2007, 124, 170-181. [CrossRef]

149. Gawronski, M.; Park, J.T.; Magee, A.S.; Conrad, H. Microfibrillar structure of PGG-glucan in aqueous solution as triple-helix aggregates by small angle $\mathrm{x}$-ray scattering. Biopolymers 1999, 50, 569-578. [CrossRef]

150. Li, B.; Allendorf, D.J.; Hansen, R.; Marroquin, J.; Ding, C.; Cramer, D.E.; Yan, J. Yeast beta-glucan amplifies phagocyte killing of iC3b-opsonized tumor cells via complement receptor 3-Syk-phosphatidylinositol 3-kinase pathway. J. Immunol. 2006, 177, 1661-1669. [CrossRef]

151. Hong, F.; Hansen, R.D.; Yan, J.; Allendorf, D.J.; Baran, J.T.; Ostroff, G.R.; Ross, G.D. $\beta$-Glucan Functions as an Adjuvant for Monoclonal Antibody Immunotherapy by Recruiting Tumoricidal Granulocytes as Killer Cells. Cancer Res. 2003, 63, 9023-9031. [PubMed] 
152. Liu, J.; Gunn, L.; Hansen, R.; Yan, J. Combined yeast-derived beta-glucan with anti-tumor monoclonal antibody for cancer immunotherapy. Exp. Mol. Pathol. 2009, 86, 208-214. [CrossRef]

153. Vetvicka, V.; Thornton, B.P.; Ross, G.D. Soluble beta-glucan polysaccharide binding to the lectin site of neutrophil or natural killer cell complement receptor type 3 (CD11b/CD18) generates a primed state of the receptor capable of mediating cytotoxicity of iC3b-opsonized target cells. J. Clin. Investig. 1996, 98, 50-61. [CrossRef] [PubMed]

154. Yan, J.; Větvička, V.; Xia, Y.; Hanikýřová, M.; Mayadas, T.N.; Ross, G.D. Critical role of Kupffer cell CR3 (CD11b/CD18) in the clearance of IgM-opsonized erythrocytes or soluble $\beta$-glucan. Immunopharmacology 2000, 46, 39-54. [CrossRef]

155. Wilczak, J.; Błaszczyk, K.; Kamola, D.; Gajewska, M.; Harasym, J.P.; Jałosińska, M.; Gudej, S.; Suchecka, D.; Oczkowski, M.; Gromadzka-Ostrowska, J. The effect of low or high molecular weight oat beta-glucans on the inflammatory and oxidative stress status in the colon of rats with LPS-induced enteritis. Food Funct. 2015, 6, 590-603. [CrossRef] [PubMed]

156. Liu, B.; Lin, Q.; Yang, T.; Zeng, L.; Shi, L.; Chen, Y.; Luo, F. Oat $\beta$-glucan ameliorates dextran sulfate sodium (DSS)-induced ulcerative colitis in mice. Food Funct. 2015, 6, 3454-3463. [CrossRef] 